\title{
Ethical Competency of Nurse Managers- Content Analysis
}

\author{
Narges Asgari¹, Hassan Navipour², Eesa Mohammadi \\ ${ }^{1}$ Department of Nursing, Faculty of Medical Sciences, Tarbiat Modares University, Tehran, Iran. ${ }^{2}$ Department of \\ Nursing, Faculty of Medical Sciences, Tarbiat Modares University, Tehran, Iran. ${ }^{3}$ Department of Nursing, Faculty of \\ Medical Sciences, Tarbiat Modares University, Tehran, Iran.
}

\section{ABSTRACT}

\section{BACKGROUND}

Ethics have a major role in activating human resources and attaining the goals of an organization. Ethical competency of nurse managers can increase the quality of care by affecting the performance of nurses and creating positive outcomes for the organization. The purpose of this study is to analyse the concept of ethical competence of nurse managers.

\section{METHODS}

This research is a qualitative study with content analysis approach. Sampling was done in hospitals in 2016-2017 and 10 nurse managers and 7 nurses were selected through purposive sampling. The data was collected through unstructured in-depth interviews using open questions. Data were analysed using conventional qualitative content analysis method.

\section{RESULTS}

The data resulted in the extraction of 10 categories and 4 themes, namely flexibility, approachability, observance of morality, and how to be a practical model. These themes express the meaning of perceived attributes of nurses and nurse managers from the ethical competency of nurse managers.

\section{CONCLUSIONS}

The results of this study, while presenting four essential characteristics of ethical competence of nurse managers, indicate the indexes related to these characteristics according to the conditions of the field. These findings can be used to design a tool for assessing ethical competence of nurse managers as well as designing empowerment programs for nurse managers.

\section{KEY WORDS}

Content, Analysis, Ethical, Competency, Nurse Manager
Corresponding Author:

Hassan Navipour,

Assistance Professor of Nursing,

Department of Nursing,

Faculty of Medical Sciences,

Tarbiat Modares University,

Tehran, Iran.

E-mail: naviporh@modares.ac.ir

DOI: $10.14260 / j e m d s / 2019 / 839$

Financial or Other Competing Interests: None.

How to Cite This Article:

Asgari N, Navipour H. Mohammadi E, Ethical competency of nurse managerscontent analysis. J. Evolution Med. Dent. Sci. 2019;8(51):3873-3877, DOI: $10.14260 /$ jemds/2019/839

Submission 15-10-2019,

Peer Review 04-12-2019,

Acceptance 10-12-2019,

Published 23-12-2019. 


\section{BACKGROUND}

Team-centered organizations, especially healthcare organizations that have dynamic, complex, and vulnerable care settings, require managers who are qualified to form competencies in the team members.[1] In an organization, for it to achieve success; it is imperative that the manager can unite subordinates in order to achieve the goals of the organization. To achieve this, the manager must have the competencies necessary. In an environment of continuous change, where managers face challenges of global business, rapid technological change and competency-based competition, they need to acquire competencies that are appropriate to the new situation.[2] also the existence of competent managers for organizational productivity is required. [3] Studies conducted by Cochran (2009), Edward (2009) and Burgalt (2006) show that Communication competence is one of the essential competencies of managers. ${ }^{[4-6]}$ And because of the important role it plays in performing tasks and providing a suitable environment for clinical care, it is one of the six competencies for health sector managers.[7]

To be competent in interpersonal communication, individuals should also be able to make informed decisions about what activity is interacting, legitimate or ethical. Communication competence researchers usually place ethics as an ethical criterion. ${ }^{[8]}$ According to Beckett, Ethics are always associated with Communication competency and an interactive one that is effective and appropriate is ethical. Because ethics moderate the interests of others and legal standards in achieving goals. ${ }^{[9]}$

The prerequisite for creating an ethical organization is the manager's ethical behaviour and it's a way for staff to be able to observe ethical behaviour and get better results.[10] Ethics can also result in quick access of goals.[11] Nurse managers can reduce nurses' turnover and increase job satisfaction for them through an appropriate ethical climate and reduce ethical problems. ${ }^{[12]}$

Although competency is one of the controversial topics in the field of health and very important in different nursing fields such as education, clinical education and nursing management, at the same time, the concept is complex and ambiguous. Although so many definitions of this concept are presented, and several studies have been published in this field. There are many ambiguities and a lot of misunderstanding in understanding this concept.[13-16]

Considering that the definition of the concept of ethical competency is not clear and precise, and its attributes are not well defined in scientific terms, those involved in the field of science or health do not have the same sense of ethical competency and especially the ethical competence of nurse managers. Therefore, the need to analyse the concept of ethical competence of nurse managers is felt.

\section{METHODS}

Because the researcher seeks to discover the inner meaning of ethical competency of nurse managers and the internal dimensions of this concept, and as this concept is related to context and culture, therefore, in order to enrich the definition of this concept, a qualitative research method was used with conventional content analysis approach.

All nurse managers such as head nurses, supervisors, and matrons employed in hospitals who had at least one year of nursing management experience formed the research community. The research environment was hospitals (natural arena). Participants in this study were nurse managers working in the hospitals. Hospital nurses were also invited to participate in the interview.

In other words, sampling with maximum variability was used to access wide and deep data. In qualitative research, sample size determination is not feasible, but is determined during the study, that is, the researcher continues sampling to reach data saturation and this is when the interview data adds any new categories to the previous categories.

Sampling method in a qualitative study is based on purpose and based on the criteria for entering the study and gradually continues until data saturation.

In the present study, interviews were stopped when no final data or new categories were produced, and all conceptual categories were completed. It was done with a total of 17 contributors, 20 interviews. Participants included 7 head nurses, 2 supervisors and 1 matron, and 7 nurses.

To identify and define the concept of the ethical competence of nurse managers, an unstructured in-depth interview was conducted using open questions. Before the interview began and the participants' voices were recorded, in addition to the previous coordination, they re-introduced themselves and, by stating the objectives of the investigation and assuring the confidentiality of the information taken from participants the interview was allowed to be recorded.

At first, one or two general open-ended questions were asked of each group of participants, such as managers (matron, supervisors and head nurses) and nurses. Considering that ethics can be explored and explained through communication, and communication is a bilateral and interpersonal issue, it is also evaluated in this way. Interviews were conducted to examine the ethical competence of head nurses by nurses, supervisors and the matron. Also, to investigate the ethical competency of supervisors the matron and head nurses were interviewed. And an interview was conducted to examine the ethical competency of the matron with the supervisor and head nurses.

Examples of open questions-

1. Please explain about your relationship with your subordinate staff as you communicate with them on a daily basis.

2. What is your assessment of this type of communication with your colleagues?

3. How is your ethical competency evaluated?

Data analysis was done apriority simultaneously with comparative and continuous data collection. After each interview, interviews were transcribed from the tape recorder.

The text of the interview was reviewed several times. Then a line was drawn under meaning units. The meaning units were reviewed several times and then the proper codes for each meaning unit were written, then the codes were classified according to conceptual and meaning similarity and 
compressed as little as possible. The downward trend in data reduction was continued in all analysis units, categories and subcategories

Finally, the data was placed in the main categories, which was more conceptual and then the themes were abstracted The analysis flow by adding each interview repeated and categories were modified.[17]

To adequately validate the findings, handwritings, interviews, and analytical units along with the original ones extracted from participants and their complementary comments were made and necessary amendments were made, and suggested points were considered. In addition, two professors in the field of qualitative research controlled and audited all phases of the study process. Sampling with maximal variance, which was expressed, increased the credibility, dependability and transferability of data.[18]

Permission for this study was obtain from the ethics committee (Code Number 3703).

\section{RESULTS}

157 initial codes and 10 categories emerged after the analysis of interviews' data. Four themes were also extracted from these data which are: flexibility, approachability, observance of morality and how to be a practical model. These themes are explained in following table based on the analysed data.

\begin{tabular}{|c|c|c|}
\hline $\begin{array}{c}\text { The Main } \\
\text { Category }\end{array}$ & Sub-Category & Initial Codes \\
\hline \multirow{4}{*}{$\begin{array}{c}\text { Communication } \\
\text { Ethics }\end{array}$} & Flexibility & $\begin{array}{c}\text { Issuing displacement permit where necessary, } \\
\text { writing monthly work-plan based on the } \\
\text { personnel preferences }\end{array}$ \\
\cline { 2 - 3 } & Approachability & $\begin{array}{c}\text { Establishing friendly and sincere } \\
\text { relationships, considering boundaries }\end{array}$ \\
\cline { 2 - 3 } & $\begin{array}{c}\text { Observance of } \\
\text { morality }\end{array}$ & $\begin{array}{c}\text { Complying with justice in workplace, respect } \\
\text { for others, secrecy }\end{array}$ \\
\cline { 2 - 3 } & $\begin{array}{c}\text { How to be a } \\
\text { practical model }\end{array}$ & $\begin{array}{c}\text { Conducting careful and accurate care in cases } \\
\text { of overcrowding, respectful relationship with } \\
\text { superiors, complying with laws individually }\end{array}$ \\
\hline \multicolumn{2}{|c|}{ Table A1. Main Category, Subcategory, and Initial Codes } \\
\hline
\end{tabular}

\section{Flexibility}

A responsible nurse manager would approve leave and displacement requests where necessary and to modify personnel's monthly work plan based on their obligations and requirements if possible.

Head Nurse 4- Sometimes we receive calls about personnel's family problems, such as a sick father or mother and child issues at school. What is the benefit of keeping such personnel at work especially when there is a high potential to make mistakes under pressure from stress? So, we ask them to leave the workplace in such circumstances. In these cases, we handle the situation the best we can and cover the absent personnel by asking for help from other sectors or making necessary coordination with emergency services in the hospital.

Nurse 2- At the beginning of each month, our head nurse wants us to submit any requests for changes in obligations such as leave request, shift preferences on special days and modified working hours to consider in the working schedule of the following month.

\section{Approachability}

An approachable nurse manager tries to establish friendly relationships with the personnel while considering privacy limitations and the boundary of professional working relationships.

Head Nurse 2-I have always tried to maintain friendship with my personnel to such an extent that our professional duties and responsibilities are not influenced negatively. Personnel want their supervisor to be approachable so they could consult with them about personal issues. But, we all know that this should not allow personnel to think that this is an opportunity to abuse the situation.

Nurse 4- She has set some limits to her privacy as a head nurse. For example, she does not allow anyone to approach her while she is in the changing room. But, other head nurses would allow their personnel to talk to them through a halfopen door. However, she is different.

\section{Observance of Morality}

A nurse manager who has a good character tries to be just with personnel about their leave/displacement requests, monthly time schedule and list of duties. They also maintain respectful relationships with their superiors and subalterns and inform personnel about their mistakes and malfunctions in privacy.

Nurse 5- At one point, some of us were working 15 day shifts and 2 nights and we were off during the weekend. This working plan was very convenient for some of us while it was extremely unpleasant for others. Actually, it was unfair. The new head nurse re-established the working schedule to make it fair and included all personnel in night shifts and day shifts regardless of their positions and years of working experience. She also considered a few shifts at the weekends for us. She argued that it doesn't make sense if some personnel always work nights. Since the new plan seemed unpleasant for some of us, including me, I called her to complain. "The new working plan is quite fair", she answered over the phone.

Head Nurse 3- When I want to reprimand personnel, who have done something wrong, I always avoid blaming personnel for their mistakes in front of others. I usually do this in private and advise them about their mistakes and remind them of the right procedures or behaviour in private such as in the rest room.

Head Nurse- In every case or issue at work, I avoid snap judgment. I listen to them carefully and let them express their feelings and thoughts. Thus, I analysed their comments because personnel's choices could be the best reaction possible in the case of emergency and conflict, while it may seem to be a mistake at $\mathrm{t}$ first glance. They should have the opportunity to provide an explanation and defend themselves. However, it is not possible to maintain 100 percent satisfaction among all and this is because of differences in opinions. For example, some decisions and situations may seem fair from my point of view while another may feel them unfair because they are not aware of all the aspects that I am. 


\section{How to Be a Practical Model}

A competent nurse manager acts as a standard for others by conducting careful and accurate care in cases of overcrowding, establishing respectful behaviour with superiors and complying with laws. They can indirectly and practically teach the personnel to follow the right procedures and establish respectful relationships with their superiors.

Nurse 4- Most head nurses used to ban personnel from bringing their cell phones to work while they themselves were always talking on their cell phones during working hours. But this specific head nurse, avoided using her personal cell phone from 7 A.M. to 2 P.M. (working hours). And this kind of approach has institutionalized the banning of cell phones among us all.

Head Nurse 2- I always stand up out of respect, as my supervisor arrives. I do this to indirectly teach my personnel to be respectful to their superiors.

Head Nurse 10- Despite my superior position, I help my personnel when they have to deal with lots of patients and are extremely busy. When my personnel see me following instructions, handling the patients and filling in the forms carefully, they will do the same for sure. If I am careless and neglectful at doing these jobs, it would come as no surprise if they do the same. So, I myself measure the patient's blood pressure and, it's common practice for me.

According to the above experiences and comments provided by some nurses and nurse managers, it can be implied that nursing supervisors can act flexibly by approving leave and displacement requests where necessary and modifying personnel's monthly work plans based on their obligations and requirements. They can also be considered available by establishing friendly relationships with the personnel while considering privacy limitations and the boundary of professional working relationships. These managers can comply with codes of ethics by being fair about their personnel's leave/displacement requests, monthly time schedule and assigned tasks. In addition, they can also maintain respectful relationships with their superiors and subalterns and inform personnel about their mistakes and negligence in privacy. Finally, nurse managers can act as a practical standard by conducting careful and accurate care in cases of overcrowding, establishing respectful behaviour with superiors and complying with laws, teaching the personnel to follow the right procedures and establish respectful relationships with their superiors.

\section{DISCUSSION}

The findings of this study showed the experiences of nurses and nurse managers on communication ethics, namely flexibility, approachability, observance of morality and how to be a practical model.

The findings of this study showed that secrecy represents a special ethical management competence that both nurses and nurse managers have come up with and fall in the ethical category. According to the results, the competent nurse manager in the event of a mistake or problem, will inform those guilty of creating a problem or making a mistake without mentioning the name of the individual, and in privacy, make the personnel in question aware. In this regard, the results of Rose et al. (2014), which aimed to explain the essential skills of nurse managers, showed that maintaining confidentiality is one of the essential skills of nurse managers.[19] The findings of this study showed that observance of justice at work is another ethical competence of nurse manager and the competent nurse manager tries to put it into practice at work in different fields such as dealing with personnel, division of labour and monthly planning, agreeing to requested programs and making sure transfer application is fair and that there is no discrimination between staff. in Rouse et al., And in Chase's study, fairness as one of the essential ethics in nurse managers has been introduced. ${ }^{[19,20]}$ In other studies, fairness and fair behaviour have been put forward in this regard.[21]

Also, the findings of this study showed that observance of respect for others represents another communication competency of nurse manager. As the results point out, the competent nurse manager tries to deal with subordinates and superiors with respect when communicating, and even if they want to oppose his decision or judgements, they try to use polite language and a respectful tone and maintain respect for superiors. This finding is in line with the results of the study by Chase and Barkhordari et al.[20,21]

Another aspect of the communication competence of nurse managers is the to be a practical model. According to the results obtained, the competent nurse manager, with careful and proper care in cases of crowdedness, acts with respect despite their superior position as well as the strict implementation of the rules by themselves as a model to their personnel, and institutionalizes the right way of doing things, enforcing laws, and communicating well with superiors as a practical and indirect example to their personnel. In this regard, the results of Rouse's (2014) and colleagues study showed that a competent nurse manager using their own personal behaviour as a role model, tried to teach and remind the specialized and non-specialized points to their personnel.[19] The findings of this study showed that flexibility is a special managerial communicative competence that both nurses and nurse managers have adopted. According to the results, the competent nurse manager agrees, if necessary, with the relocation of the work plan of personnel and adjusts the monthly work schedule based on the application of the personnel. In the same way, Chase discusses flexibility in his content analysis as one of the competencies of nurse managers.[20]

Also, at the same time, Barkhordari and his colleagues in the study of content analysis said that nurse managers, in the event of an employee's problem while facilitating working conditions, helps them identify and resolve the problem. A subcategory of problem solving and aspirations in Barkhordari study, with the theme of flexibility in the present study is consistent and similar.[21]

The findings of this study showed that to be approachable indicates a special managerial competence that both nurses and nurse managers have adopted. According to the results, 
the competent nurse manager tries to establish friendly and sincere relationships with his personnel while at the same time emphasizing privacy limitations... In the same way, Chase, in the results of his study, open door openness policy,[20] and Chang et al., introduced open door openness and accessibility,[22] and Barkhordari and his colleagues mentioned that access to mutual friendship and respect, are among the ethical competency of nurse managers.[21]

\section{CONCLUSIONS}

The results of this research have led to the discovery of the real meaning of the ethical competence of nurse managers. Flexibility, approachability, observance of morality, and how to be a practical model, are among the attributes of ethical competence of nurse managers who will lead to quantitative and qualitative managerial advancement. Given that the current research is the result of a field study based on the actual experiences and perception of nurses and nurse managers, it can provide a proper and realistic definition of the ethical competency of nurse managers and be used to design a tool for evaluating ethical competency of nurse managers.

\section{REFERENCES}

[1] Tucker JL. The moderators of patient satisfaction. Journal of Management in Medicine 2002;16(1):48-66.

[2] Viitala R. Perceived development needs of managers compared to an integrated management competency model. Journal of Workplace Learning 2005;17(7):43651.

[3] Riggio RE, Lee J. Emotional and interpersonal competencies and leader development. Human Resource Management Review 2007;17(4):418-26.

[4] Cochran GR. Ohio State University Extension Competency Study: Developing a Competency Model for a 21st Century Extension Organization. The Ohio State University, 2009.

[5] Edwards A. Competency modeling as an antecedent for effective Leadership development and succession planning within the public social services environment, 1346. Dissertation for Degree of Doctor of Philosophy. Benedictine University, 2009.

[6] Bourgault J, Charih M, Maltais D. Hypotheses concerning the prevalence of competencies among government executives, according to three organizational variables. Public Personnel Management 2006;35(2):89-119.
[7] Zineldin M. The quality of health care and patient satisfaction: an exploratory investigation of the $5 \mathrm{Qs}$ model at some Egyptian and Jordanian medical clinics. Int J of Health Care Qual Assur Inc Leadersh Health Serv 2006;19(1):60-92.

[8] Purhonen P. Interpersonal communication competence in SME Internationalization. Networking Knowledge: Journal of the MeCCSA Postgraduate Network 2007;1(2):1-16.

[9] Beckett R. Communication ethics: principle and practice. Journal of Communication Management 2004;8(1):4152.

[10] Hazrati MS, Alvani SM, Zadeh GRM. The presentation of modeling an ethical leadership consistent with public organizations in Iran. European Online Journal of Natural and Social Sciences 2015;2(Special IssNo. 3):3429-39.

[11] Bogdanović M. Basic roots of managers' ethical competencies. Integrity in Organizations 2013: p. 54175.

[12] Keselman D. Ethical leadership. Holistic Nursing Practice 2012;26(5):259-61.

[13] Meretoja R, Leino-Kilpi H. Comparison of competence assessments made by nurse managers and practising nurses. Journal of Nursing Management 2003;11(6):4049.

[14] McMullan M, Endacott R, Gray MA, et al. Portfolios and assessment of competence: a review of the literature. Journal of Advanced Nursing 2003;41(3):283-94.

[15] Shewchuk RM, O'Connor SJ, Fine DJ. Building an understanding of the competencies needed for health administration practice. Journal of Healthcare Management 2005;50(1):32-47.

[16] Fordham AJ. Using a competency based approach in nurse education. Nursing Standard 2005;19(31):41-8.

[17] Krippendorff K. Content analysis: an introduction to its methodology. Fourth editipon. SAGE Publications 2018.

[18] Sandelowski M. Whatever happened to qualitative description? Research in Nursing \& Health 2000;23(4):334-40.

[19] Rouse RA, Al-Maqbali M. Identifying nurse managers' essential communication skills: an analysis of nurses' perceptions in Oman. Journal of Nursing Management 2014;22(2):192-200.

[20] Chase L. Nurse manager competencies. Journal of Nursing Administration 1994;24(Suppl 4):56-64.

[21] Barkhordari-Sharifabad M, Ashktorab T, AtashzadehShoorideh F. Ethical competency of nurse leaders: a qualitative study. Nursing Ethics 2018;25(1):20-36.

[22] Chang S, Tharenou P. Competencies needed for managing a multicultural workgroup. Asia Pacific Journal of Human Resources 2004;42:57-74. 